\title{
Magnesium Decreases Inflammatory Cytokine Production: A Novel Innate Immunomodulatory Mechanism
}

\author{
Jun Sugimoto ${ }^{\star}$, Andrea M. Romani ${ }^{\dagger}$, Alice M. Valentin-Torres ${ }^{\ddagger}$, Angel A. Luciano§, \\ Christina M. Ramirez Kitchenף, Nicholas Funderburg ${ }^{\ddagger}$, Sam Mesiano*, and Helene B. \\ Bernstein ${ }^{*}, \ddagger$ \\ "Department of Reproductive Biology, Case Western Reserve University School of Medicine, \\ Cleveland, $\mathrm{OH} 44106$ \\ tDepartment of Physiology and Biophysics, Case Western Reserve University School of \\ Medicine, Cleveland, $\mathrm{OH} 44106$ \\ ‡Department of Molecular Biology and Microbiology, Case Western Reserve University School of \\ Medicine, Cleveland, $\mathrm{OH} 44106$ \\ $\S$ Division of Neonatology, Department of Pediatrics, College of Medicine, University of South \\ Florida, Tampa, FL 33606 \\ IDepartment of Biostatistics, School of Public Health, University of California at Los Angeles, Los \\ Angeles, CA 90095
}

\section{Abstract}

\begin{abstract}
$\mathrm{MgSO}_{4}$ exposure before preterm birth is neuroprotective, reducing the risk of cerebral palsy and major motor dysfunction. Neonatal inflammatory cytokine levels correlate with neurologic outcome, leading us to assess the effect of $\mathrm{MgSO}_{4}$ on cytokine production in humans. We found reduced maternal TNF- $\alpha$ and IL-6 production following in vivo $\mathrm{MgSO}_{4}$ treatment. Short-term exposure to a clinically effective $\mathrm{MgSO}_{4}$ concentration in vitro substantially reduced the frequency of neonatal monocytes producing TNF- $a$ and IL-6 under constitutive and TLRstimulated conditions, decreasing cytokine gene and protein expression, without influencing cell viability or phagocytic function. In summary, $\mathrm{MgSO}_{4}$ reduced cytokine production in intrapartum women, term and preterm neonates, demonstrating effectiveness in those at risk for inflammationassociated adverse perinatal outcomes. By probing the mechanism of decreased cytokine production, we found that the immunomodulatory effect was mediated by magnesium and not the sulfate moiety, and it was reversible. Cellular magnesium content increased rapidly upon $\mathrm{MgSO}_{4}$ exposure, and reduced cytokine production occurred following stimulation with different TLR ligands as well as when magnesium was added after TLR stimulation, strongly suggesting that magnesium acts intracellularly. Magnesium increased basal IKBa levels, and upon TLR stimulation was associated with reduced NF- $\kappa$ B activation and nuclear localization. These findings establish a new paradigm for innate immunoregulation, whereby magnesium plays a critical regulatory role in NF- $\kappa \mathrm{B}$ activation, cytokine production, and disease pathogenesis.
\end{abstract}

Copyright (92012 by The American Association of Immunologists, Inc.

Address correspondence and reprint requests to Dr. Helene B. Bernstein, Case Western Reserve University, Wood Building, W210D, 10900 Euclid Avenue, Cleveland, OH 44106-4960. hbb22@case.edu.

The online version of this article contains supplemental material.

Disclosures

The authors have no financial conflicts of interest. 
Magnesium sulfate is widely used in obstetrics for seizure prophylaxis in preeclampsia and as a tocolytic to arrest preterm labor. Despite widespread use, the mechanism by which $\mathrm{MgSO}_{4}$ exerts its action is poorly understood. Retrospective, clinical studies associated antepartum $\mathrm{MgSO}_{4}$ exposure with reduced risk of adverse neurologic outcome in premature newborns $(1,2)$, leading to randomized clinical trials (3-7); additionally, a recent review concluded that antenatal $\mathrm{MgSO}_{4}$ therapy significantly reduces the risk of cerebral palsy and substantial gross motor dysfunction (8). These findings raise a critical question, "How does $\mathrm{MgSO}_{4}$ mediate neuroprotection?"

Cerebral palsy is the most common cause of pediatric motor dysfunction (9). Multiple prospective studies strongly associate cerebral palsy with antepartum and intrapartum inflammation, whereas isolated birth asphyxia accounts for $<10 \%$ of the cases $(9,10)$. These conclusions are supported by animal studies demonstrating that proinflammatory cytokines are neurotoxic, causing CNS damage (11), as well as by epidemiologic research correlating increased neonatal serum levels of inflammatory cytokines with adverse neurologic outcome $(12-18)$. Preterm parturition is associated with a fetal inflammatory response syndrome defined by increased cord blood IL-6 levels (19), as well as increased levels of IL-1, IL-8, RANTES, TNF-a, and other inflammatory cytokines (20). Magnesium sulfate is used both as a tocolytic to arrest preterm labor and for seizure prophylaxis in women with preeclampsia, a condition sharing features with atherosclerosis, including endothelial dysfunction and systemic inflammation $(21,22)$. Inflammation is also linked to seizure activity. A very recent study linked TLR4 signaling to seizure activity; remarkably, seizure activity was ameliorated with TLR4 antagonists, supporting a mechanism of inflammationinduced seizure ictogenesis (23).

Inflammation plays a central role in the three conditions for which $\mathrm{MgSO}_{4}$ is used as therapy: 1) to treat preterm labor, 2) to prevent preeclamptic seizures, and 3) to reduce the development of cerebral palsy. This led us to hypothesize that $\mathrm{MgSO}_{4}$ exerts its neuroprotective effect by downregulating inflammatory cytokine production in neonates. Following in vivo $\mathrm{MgSO}_{4}$ treatment, we observed a reduced frequency of monocytes producing TNF- $\alpha$ and IL-6 in women receiving $\mathrm{MgSO}_{4}$ for clinical indications. Exposing peripheral and/or cord blood mononuclear cells in vitro to $\mathrm{MgSO}_{4}$ yielded similar results.

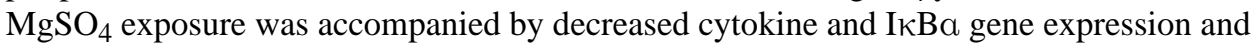
diminished NF- $\kappa \mathrm{B}$ activation; moreover, reduced cytokine production was observed following exposure to different TLR ligands, suggesting that magnesium has broad antiinflammatory activity. Taken together, our data establish a new paradigm for innate immunoregulation whereby magnesium plays a critical regulatory role in NF- $\kappa \mathrm{B}$ activation, cytokine production, and disease pathogenesis.

\section{Materials and Methods}

\section{Abs and reagents}

LPS (from Escherichia coli 0111:B4) and brefeldin A were from Sigma-Aldrich (St. Louis, MO). Macrophage-activating lipopeptide (MALP)-2 was purchased from Imgenex. Polyinosinic-polycytidylic acid (poly(I:C)) was provided by Dr. Aaron Weinberg of Case Western Reserve University. Fluorochrome-labeled Abs and reagents used were: FITCannexin V, PE-anti-CD14, PerCP-anti-CD3, and allophycocyanin-anti-TNF-a from BD Biosciences, FITC-anti-CD14, allophycocyanin-anti-CD4, PE-anti-CD56, and ECD-antiCD19 were from Beckman Coulter, and PE-anti-IL-6 was from R\&D Systems. Mouse antiI $\mathrm{Ba}$ (L35A5) was obtained from Cell Signaling Technology, mouse anti-tubulin (DM1A) was obtained from Sigma-Aldrich, and rabbit anti-TFIID (TBP) (N-12) and NF- $k B$ p65 (C-20) were obtained from Santa Cruz Biotechnology. 


\section{Cell isolation and culture}

Anti-coagulated umbilical cord blood and peripheral blood were collected under protocols approved by the University Hospitals Institutional Review Board; all donors provided written informed consent. Mononuclear cells were isolated by density gradient centrifugation on lymphocyte separation medium (density, 1.077-1.080 g/ml) (Mediatech). Monocytes were purified by positive selection using anti-CD14 magnetic beads (Miltenyi Biotec), and cultures were maintained in RPMI 1640 (HyClone; magnesium concentration is $1 \mathrm{mg} / \mathrm{dl}$ or $0.4 \mathrm{mM}$ ) supplemented with $10 \%$ heat-inactivated human serum from male $\mathrm{AB}$ donors (HAB) (Sigma-Aldrich), $2 \mathrm{mM} \mathrm{L-glutamine,} 100 \mathrm{IU} / \mathrm{ml}$ penicillin, and $100 \mu \mathrm{g} / \mathrm{ml}$ streptomycin. Cells were supplemented with $\mathrm{MgSO}_{4}$ to a final concentration of $60 \mathrm{mg} / \mathrm{l}$ or $2.5 \mathrm{mM}$, a concentration known to be clinically effective. THP-1 cells were obtained from the Skowronski Laboratory and maintained in media described above, supplemented with $10 \%$ FCS. Cyclohexamide (Sigma-Aldrich) was used at $100 \mu \mathrm{g} / \mathrm{ml}$ to inhibit protein synthesis, whereas $10 \mu \mathrm{M}$ 6-amino-4-(4-phenoxyphenylethylamino)quinazoline and $80 \mu \mathrm{M}$ 4-methyl- $N^{1}$-(3-phenylpropyl)benzene-1,2-diamine (JSH-23) (Calbiochem) were used to inhibit NF- $\kappa \mathrm{B}$ activation.

\section{TLR ligand stimulation}

Mononuclear cells $\left(1 \times 10^{6}\right.$ cells $\left./ \mathrm{ml}\right)$ were cultured in six-well plates and in some cases stimulated with $50 \mathrm{pg} / \mathrm{ml}$ LPS, $1-10 \mathrm{ng} / \mathrm{ml}$ MALP-2, or $0.1-1.0 \mu \mathrm{g} / \mathrm{ml}$ poly(I:C) for $6 \mathrm{~h}$. For the dose-response determination, $0-1 \mu \mathrm{g} / \mathrm{ml}$ LPS was used.

\section{Intracellular cytokine staining}

Two hours following the addition of TLR ligands, brefeldin A was added to inhibit cytokine secretion $(1 \mu \mathrm{g} / \mathrm{ml}$; Sigma-Aldrich). Cells were harvested and blocked with excess HAB (5\% HAB in PBS). Cells were stained with FITC-conjugated anti-CD14 Ab. After fixation with $2 \%$ paraformaldehyde, cells were permeabilized using $1 \times$ Perm/Wash buffer $(\mathrm{BD}$ Biosciences), blocked with 5\% HAB, followed by staining with intracellular Abs (ICS), allophycocyanin-conjugated anti-TNF-a, and PE-conjugated anti-IL-6, followed by flow cytometric analysis (BD FACSCalibur, FlowJo). Maternal whole blood ( $1 \mathrm{ml}$ ) was stimulated by the direct addition of TLR ligands and brefeldin A as described above, followed by surface staining, fixation, and RBC lysis using BD FACS Lyse solution and ICS as described above.

\section{Quantitative PCR}

Total RNA was extracted using RNeasy (Qiagen) with QIAshredders according to the manufacturer's protocol. Single-stranded cDNA was synthesized using TaqMan reverse transcription reagents (Applied Bio-systems) in a thermal cycler. Quantitative PCR was carried out in an ABI Prism sequence detection system. Cycling conditions were: $95^{\circ} \mathrm{C}$ for $10 \mathrm{~min}$, followed by 40 cycles of $95^{\circ} \mathrm{C}$ for $15 \mathrm{~s}$ and $60^{\circ} \mathrm{C}$ for $1 \mathrm{~min}$ using Power SYBR Green PCR Master Mix (Applied Biosystems) with relative quantification methods. All reactions yielded a single amplification product. Primers used for quantitative PCR included: TNF- $a$, sense, 5'-AGT-GACAAGCCTGTAGCCCATGTT-3', anti-sense, 5' GTTATCTCTCAGC TCCACGCCATT-3'; IL-6, sense, 5'ACCTGAACCTTCCAAAGATGG-CTG-3', anti-sense, 5' ACTCATCTGCACAGCTCTGG CTT-3'; I $\kappa \mathrm{Ba}$, sense, 5'AAGTGATCCGCCAGGTGAAG-3' , anti-sense, 5'-TGCTGC-AGGTTGTTCTGGAA-3'; Gus, sense, 5'-AGCAGTACCATCTGGGT-CTG-3', anti-sense, 5'TTGGTTGTCTCTGCCGAGTG-3'. Values were normalized to human Gus ( $\beta$ glucuronidase), expression of this gene was found to be stable during stimulation, and the 
value of unstimulated cells at time 0 was set to 1 and used to calculate the fold change in stimulated cells. Results are mean values of triplicates.

\section{Phagocytosis assays}

To determine the effect of magnesium on monocyte phagocytic function, cord blood mononuclear cells (CBMCs) in the presence or absence of magnesium supplementation were exposed to either 0.1 or $0.5 \mu \mathrm{M}$ FITC-conjugated latex beads or Alexa Fluor 488conjugated albumin $(5 \mu \mathrm{l} / \mathrm{ml})$ for $2-4 \mathrm{~h}$ (a gift from the Canaday Laboratory). Cell identification and substrate uptake on a per cell basis was quantitated via flow cytometry to assess fluid phase-type endocytosis and macropinocytosis.

\section{Western blot analysis}

Cells were stimulated with LPS for 30 min and lysed in $1 \times$ SDS loading buffer $(62.5 \mathrm{mM}$ Tris-HCl, 2\% [w/v] SDS, 10\% glycerol, $50 \mathrm{mM}$ DTT, $0.01 \%$ [w/v] bromophenol blue). Lysates were heated to $95^{\circ} \mathrm{C}$ for $5 \mathrm{~min}$, and samples were resolved by SDS-PAGE on $12 \%$ Tris-HCl Ready Gels (Bio-Rad, Hercules, CA) and transferred to nitrocellulose membranes (Amersham Biosciences, Piscataway, NJ). Phosphorylated proteins were detected by using primary monoclonal Abs to p-NF- $\kappa$ B p65 (Ser ${ }^{536}$ ) (Cell Signaling Technology, Beverly, MA). mAbs to actin (Santa Cruz Bio-technology, Santa Cruz, CA) were used to confirm comparable protein loading between specimens. Secondary anti-rabbit HRP-conjugated Abs were used to detect primary Abs (Cell Signaling Technology). Following incubation with HRP-conjugated secondary Abs, proteins were detected by chemiluminescence (Western Lightning; PerkinElmer Life Sciences, Boston, MA) and were visualized by x-ray film exposure (Denville Scientific, Metuchen, NJ).

Nuclear and cytoplasmic proteins were obtained by washing cells twice in ice-cold PBS. Cells were resuspended in cytosolic extract lysis buffer (10 mM HEPES-KOH [pH 7.9], 10 $\mathrm{mM} \mathrm{KCl}, 1 \mathrm{mM}$ EDTA, $1.5 \mathrm{mM} \mathrm{MgCl} 2,1 \mathrm{mM}$ DTT, and $1 \mathrm{mM}$ PMSF) containing protease inhibitor mixture (Roche) and incubated on ice for $10 \mathrm{~min}$ as described (24). Nuclei were pelleted by centrifugation for $10 \mathrm{~min}$ at $4000 \mathrm{rpm}$, cytoplasmic extracts were collected, and nuclei were washed three times in cytosolic extract lysis buffer. RIPA buffer $(20 \mathrm{mM}$ Tris [pH 7.5], $150 \mathrm{mM} \mathrm{NaCl}, 0.5 \%$ Triton X-100, $0.5 \%$ sodium deoxycholate, $0.1 \%$ SDS, $5 \mathrm{mM}$ EDTA) with protease inhibitors was added to nuclei, which were sonicated prior to collection of nuclear protein containing supernatants. Protein concentrations were determined using the BCA protein assay kit (Pierce) or the Bradford reagent (Bio-Rad). The NuPAGE system (Invitrogen) was used to resolve and transfer proteins on a 4-12\% Bis-Tris gel. Protein bands on polyvinylidene difluoride membranes were detected and quantified by Western blotting with the Odyssey system imager (Li-Cor Biosciences) using IRDye $800 \mathrm{CW}$ goat anti-mouse IgG and IRDye $800 \mathrm{CW}$ goat anti-rabbit IgG.

\section{Magnesium determination}

Total cellular $\mathrm{Mg}^{2+}$ content was assessed by atomic absorbance spectrophotometry in a PerkinElmer 3100 (PerkinElmer, Waltham, MA), as reported previously (25). Briefly, aliquots of cells $\left(1 \times 10^{5}\right)$ exposed or not to $2.5 \mathrm{mM}$ extracellular $\mathrm{Mg}^{2+}$ were rapidly sedimented through a $0.5-\mathrm{ml}$ oil layer (dibutyl phthalate/dioctyl phthalate 2:1 [v/v]) in microfuge tubes at 14,000 rpm for $5 \mathrm{~min}$. The supernatant and oil layer were removed, and the cell pellets were digested overnight in $0.5 \mathrm{ml} 10 \% \mathrm{HNO}_{3}$. Following sedimentation of denatured protein at 14,000 rpm for $5 \mathrm{~min}$ in Microfuge tubes, the $\mathrm{Mg}^{2+}$ content of the acid extracts was measured by atomic absorbance spectrophotometry calibrated with appropriate standards. 


\section{Statistical analysis}

Data are expressed and plotted as means \pm standard deviations. A Wilcoxon signed-rank test was used to compare differences between related samples; for poly(I:C) stimulation and maternal blood stimulation, means were compared using a Student $t$ test. Statistical significance was defined as $p<0.05$ as indicated.

\section{Results}

\section{In vivo $\mathrm{MgSO}_{4}$ therapy reduces monocyte-mediated cytokine production}

To determine the in vivo effect of $\mathrm{MgSO}_{4}$ exposure, we assessed cytokine production within heparinized blood samples obtained from women immediately prior to initiating $\mathrm{MgSO}_{4}$ therapy and 6-12 $\mathrm{h}$ after beginning $\mathrm{MgSO}_{4}$ therapy for clinical indications. Cytokine production was assessed in untouched and LPS-challenged whole blood from the same donor via ICS. We found that in vivo $\mathrm{MgSO}_{4}$ treatment significantly decreased the frequency of maternal cells producing TNF-a and IL-6 (Fig. 1). The frequency of TNF-aproducing cells was reduced by $25 \%(p=0.03, n=7)$, and relative TNF- $a$ expression as determined by the median fluorescence intensity was reduced by $27 \%$. Induction of IL-6 production was reduced by $\sim 20 \%(p<0.05, n=7)$ as assessed by both a reduced cell frequency and median fluorescence intensity, and monocytes comprised most of the cytokine-producing cells.

Circulating monocytes compromise $10 \%$ of mononuclear cells, playing a key role in systemic inflammation and cytokine production and differentiating into macrophages when recruited into tissue. We next assessed whether in vitro exposure to $\mathrm{MgSO}_{4}$ influences cytokine production. A dose-response curve measuring the effect of LPS on TNF-a production was established using PBMCs. LPS concentrations of $1 \mu \mathrm{g} / \mathrm{ml}$ are typically used for in vitro stimulation assays (26). However, in our assay conditions an LPS concentration of $50-100 \mathrm{pg} / \mathrm{ml}\left(5 \times 10^{-5}-10^{-4} \mu \mathrm{g} / \mathrm{ml}\right)$ generated $\sim 50 \%$ of the maximal response, permitting assessment of the influence of $\mathrm{MgSO}_{4}$ on cytokine production. This LPS concentration is above the mean plasma LPS concentration $(25 \mathrm{pg} / \mathrm{ml})$ within normal, adult nonbacteremic individuals (27). Overall, these results demonstrate that in vivo $\mathrm{MgSO}_{4}$ treatment decreases the frequency of cells producing inflammatory cytokines and establishes in vitro conditions for further analysis.

\section{$\mathrm{MgSO}_{4}$ reduces monocyte-mediated IL- 6 and TNF- $\alpha$ production in neonates}

Because neonatal serum cytokine levels are associated with the development of cerebral palsy, we assessed the influence of $\mathrm{MgSO}_{4}$ exposure on cytokine production within CBMCs. Magnesium rapidly crosses the placenta, resulting in equivalent maternal and fetal levels, so CBMCs were cultured under standard, physiologic conditions or exposed to $6 \mathrm{mg} /$ dl $\mathrm{MgSO}_{4}$, a clinically effective maternal magnesium concentration. Magnesium supplementation significantly decreased the frequency of LPS-stimulated cord blood monocytes producing IL-6 and TNF-a (Fig. 2A); the results of multiple patients are shown in Fig. 2B ( $p<0.01$, Wilcoxon signed-rank test). Magnesium supplementation also significantly decreased IL-6 and TNF-a expression by $>60 \%(p<0.05)$, as measured by median fluorescence intensity; these results were confirmed by measuring secreted cytokines via ELISA (data not shown). Cytokine production is much lower in unstimulated cells, but $\mathrm{MgSO}_{4}$ also significantly reduced the frequency of neonatal monocytes producing TNF- $\alpha$ and IL-6 under constitutive or unstimulated conditions (Fig. 2C; $p<0.01$ and $p<$ 0.05 , respectively; Wilcoxon signed-rank test).

To rule out the possibility that decreased cytokine production in monocytes was secondary to altered cell viability or function, we quantitated cell count and composition via flow 
cytometry after overnight culture under standard conditions or in the presence of magnesium supplementation. When examining $\mathrm{T}$ cell $\left(\mathrm{CD}^{+}\right.$and $\left.\mathrm{CD} 8^{+}\right)$, B cell, NK cell, and monocyte populations, no differences in cell counts or apoptosis (as assessed via annexin $\mathrm{V}$ staining) were found within individual donors in the presence and absence of $\mathrm{MgSO}_{4}$ supplementation (data not shown). To evaluate an additional aspect of monocyte function, we assessed phagocytosis using FITC-labeled 0.1 and $0.5 \mu \mathrm{M}$ latex beads and Alexa Fluor 488-conjugated albumin. No differences in fluid phase-type endocytosis or macropinocytosis were observed in the presence of magnesium supplementation (Supplemental Fig. 1), suggesting that monocyte function is intact.

\section{$\mathrm{MgSO}_{4}$ reduces cytokine production in monocytes from preterm neonates}

$\mathrm{MgSO}_{4}$ has been demonstrated to have a neonatal neuroprotective effect when given to women at risk for preterm delivery (3-7). We observed that $\mathrm{MgSO}_{4}$ supplementation decreases baseline and LPS-stimulated TNF- $a$ and IL-6 production within CBMCs from preterm neonates who were not exposed to $\mathrm{MgSO}_{4}$ intrapartum (Fig. 3). These findings suggest that the effect of $\mathrm{MgSO}_{4}$ is not gestational age-dependent, and more importantly that $\mathrm{MgSO}_{4}$ decreases cytokine production in the population at highest risk for adverse neurologic outcomes. One limitation of this assay is that $\mathrm{MgSO}_{4}$ supplementation was provided in vitro, as ethical and technical constraints prevent obtaining human fetal blood samples prior to antepartum $\mathrm{MgSO}_{4}$ treatment. Cumulatively, our results demonstrate that both in vivo and in vitro $\mathrm{MgSO}_{4}$ exposure downregulates the production of cytokines associated with adverse neurologic outcomes under both constitutive and TLR ligandstimulated conditions; moreover, $\mathrm{MgSO}_{4}$ decreases cytokine production in patients at risk for these outcomes.

\section{Decreased cytokine production is mediated by intracellular magnesium}

To evaluate how $\mathrm{MgSO}_{4}$ reduces cytokine production, we measured total cellular magnesium levels following $\mathrm{MgSO}_{4}$ exposure, observing a rapid rise in cellular magnesium content. Within $1 \mathrm{~h} \mathrm{MgSO} 4$ supplementation (final concentration, $6 \mathrm{mg} / \mathrm{dl}$ or $2.5 \mathrm{mM}$ ), the

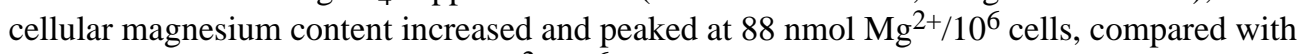
a magnesium content of $24 \mathrm{nmol} \mathrm{Mg}{ }^{2+} / 10^{6}$ in cells cultured in RPMI 1640/10\% HAB (standard conditions, control). Because the possibility exists that magnesium functions extracellularly by decreasing LPS/TLR4 binding, we performed experiments where CBMCs were challenged with LPS for 15 min (to permit LPS/TLR4 binding) prior to $\mathrm{MgSO}_{4}$ supplementation. Under these conditions cytokine production was decreased, supporting the concept that magnesium exerts its effect downstream of LPS/TLR binding (Fig. 4A; $p<$ 0.05 for IL- 6 and $p<0.01$ for TNF-a). Taken together, these findings support the concept that magnesium rapidly influences cytokine production via an intracellular mechanism.

The specificity of magnesium in downregulating inflammatory cytokine production was assessed by exposing cells from a single donor to equimolar concentrations of $\mathrm{MgSO}_{4}$, $\mathrm{MgCl}_{2}$, or $\mathrm{Na}_{2} \mathrm{SO}_{4}$ followed by LPS stimulation. Supplementation with either $\mathrm{MgCl}_{2}$ or $\mathrm{MgSO}_{4}$ comparably reduced IL-6 (60-70\%) and TNF-a (40-50\%) production, whereas exposure to $\mathrm{Na}_{2} \mathrm{SO}_{4}$ did not decrease cytokine production, indicating that the magnesium moiety influences cytokine production (Fig. 4B; $p<0.01$ ). Furthermore, these compounds served as osmotic controls. Hence, the ineffectiveness of $\mathrm{Na}_{2} \mathrm{SO}_{4}$ at reducing cytokine production rules out an osmotic effect as a possible cause of altered cytokine production. Cumulatively, these data indicate that the immunomodulatory effect is mediated by magnesium and not the sulfate moiety of the compound and that magnesium functions intracellularly. 


\section{Magnesium reversibly regulates cytokine production via transcriptional regulation}

To assess whether the effects of magnesium are reversible, cells were exposed (or not) to $\mathrm{MgSO}_{4}$ for $2 \mathrm{~h}$; cells were then washed and immediately challenged with LPS in the presence of control or magnesium-supplemented media. The effect of magnesium was reversible, because exposure prior to LPS challenge had minimal influence on the ability of cells to produce IL-6 and TNF-a (Fig. 5). These results are consistent with the swift rise and peak in cellular magnesium concentrations observed following $\mathrm{MgSO}_{4}$ supplementation. By pursuing the mechanism of diminished cytokine production, cytokine gene expression within TLR-ligand stimulated cells exposed to $\mathrm{MgSO}_{4}$ was assessed using real-time PCR (Fig. 6). At 2 and $4 \mathrm{~h}$ after LPS exposure there was a statistically significant decrease $(p<$ 0.05 ) in TNF-a and IL-6 mRNA levels within cells receiving $\mathrm{MgSO}_{4}$ supplementation. These results indicate that $\mathrm{MgSO}_{4}$ downregulates TNF- $\mathrm{a}$ and IL-6 production prior to transcription.

\section{Magnesium decreases cytokine production by reducing NF-KB activation}

The impact of $\mathrm{MgSO}_{4}$ on NF- $\kappa \mathrm{B}$ activation was evaluated using multiple independent methods. First, we assessed I $\kappa \mathrm{B} a$ gene expression, as NF- $\kappa \mathrm{B}$ activation leads to increased transcription of its repressor, I $\kappa \mathrm{Ba}$. Magnesium supplementation decreased TLR-induced I $\kappa \mathrm{Ba}$ mRNA levels 3 -fold $1 \mathrm{~h}$ after stimulation, suggesting that NF- $\kappa \mathrm{B}$ activation is decreased in the presence of increased cellular magnesium levels (Fig. 7A). We next determined the impact of $\mathrm{MgSO}_{4}$ on NF- $\mathrm{BB}$ p65 phosphorylation. Activated NF- $\kappa \mathrm{B}$ p65 is phosphorylated at $\mathrm{Ser}^{536}$, regulating activation, nuclear localization, and transcriptional activity. Exposure to magnesium was correlated with diminished phosphorylated NF- $\kappa$ B p65 levels following TLR stimulation (Fig. 7B), providing further evidence that magnesium downregulates TLR-induced inflammatory cytokine production in an NF- $\kappa \mathrm{B}-$ dependent manner. We next assessed nuclear NF- $\kappa \mathrm{B}$ levels in purified neonatal monocytes, whereby we demonstrate a 3- to 4-fold increase in nuclear NF- $\kappa$ B levels following LPS stimulation (Fig. 7C; the NF- $\kappa \mathrm{B}$ p65/TFIID ratio is shown below each lane). In the presence of magnesium supplementation, LPS-stimulated nuclear NF- $\kappa \mathrm{B}$ levels were reduced by half, confirming decreased NF- $\kappa \mathrm{B}$ activation. The mechanism of magnesium-reduced NF- $\kappa \mathrm{B}$ activation leading to decreased cytokine production was confirmed using the NF- $\kappa \mathrm{B}$ specific inhibitors 6-amino-4-(4-phenoxyphenylethylamino)quinazoline and 4-methyl- $N^{1}$-(3phenylpropyl)benzene-1,2-diamine (JSH-23). These inhibitors reduced TNF-a expression by 80 and $50 \%$, respectively, eliminating reduced cytokine production within magnesiumsupplemented cells.

\section{Magnesium decreases TLR-mediated cytokine production by increasing IKBa levels}

Pathogens associated with preterm parturition include group B Streptococcus, Mycoplasma, and Ureaplasma. These clinically relevant perinatal pathogens express molecules interacting with TLR2 (28) leading to NF- $\kappa \mathrm{B}$ activation, prompting us to investigate whether $\mathrm{MgSO}_{4}$ supplementation also impacts cytokine production following TLR2 ligand stimulation. Using MALP-2, a synthetic TLR2/6 ligand (29), at a concentration determined to induce IL-6 production in $\sim 50 \%$ of neonatal monocytes, we found that $\mathrm{MgSO}_{4}$ supplementation significantly reduces the percentage of monocytes producing TNF-a and IL-6 following TLR2/6 stimulation (Fig. 8A; $p<0.01$ ). This strongly suggests that our findings are applicable to pathogens likely to be encountered within an obstetrical setting. We next investigated whether $\mathrm{MgSO}_{4}$ influences TLR3 signaling. TLR3 recognizes dsRNA and is present within the lysosomal compartment, signaling via an MyD88-independent pathway. $\mathrm{MgSO}_{4}$ supplementation resulted in diminished cytokine production following TLR3 signaling (Fig. 8B; $p<0.01$ ), providing additional evidence that intracellular magnesium influences cytokine production. 
Because I $\kappa \mathrm{Ba}$ is the first signaling molecule in the NF- $\kappa \mathrm{B}$ pathway used by all of the TLRs we assessed (TLRs 2, 3, 4, and 6), we measured monocyte I $\kappa \mathrm{Ba}$ levels. As shown in Fig. 9A, IkBa levels were reduced following TLR stimulation, and magnesium supplementation did appear to inhibit I $\kappa$ B a degradation. However, quantitating I $\kappa$ B $a$ by fluorochromelabeled secondary Abs and normalizing expression to tubulin levels we observed that basal I $\mathrm{Ba}$ levels were increased $25 \%$ in magnesium-supplemented cells. Moreover, following LPS stimulation, I $\mathrm{B} a$ levels in magnesium-supplemented cells remained slightly elevated for our 1-h-long assessment. Magnesium did not influence basal I $\kappa \mathrm{Ba}$ gene expression (data not shown), leading us to question how magnesium modulates I $\kappa \mathrm{B} a$ levels. We next quantitated I $\kappa \mathrm{B} a$ in unstimulated THP-1 cells, some of which were treated with cyclohexamide before and during magnesium exposure to inhibit protein synthesis. We found that both treated and untreated cells had increased I $\kappa \mathrm{B} a$ levels in the presence of magnesium supplementation, with enhanced preservation of I $\mathrm{KB}$ levels in the presence of cyclohexamide (Fig. 9B). These results support the concept that magnesium supplementation increases constitutive I $\kappa \mathrm{B} a$ levels, leading to reduced $\mathrm{NF}-\kappa \mathrm{B}$ activation and cytokine production.

\section{Discussion}

To our knowledge, this study shows for the first time that in vitro and in vivo exposure to a clinically effective $\mathrm{MgSO}_{4}$ concentration $(6 \mathrm{mg} / \mathrm{dl}$ ) decreases constitutive and TLRstimulated TNF-a and IL-6 production. Decreased cytokine production is observed in both adults and neonates and is mediated via increased constitutive I $\kappa \mathrm{B} a$ levels and reduced NF$\kappa \mathrm{B}$ activation and nuclear localization. Our results define a novel immunomodulatory function for $\mathrm{MgSO}_{4}$, whereby it regulates NF- $\mathrm{kB}$ activation, cytokine production, and limits systemic inflammation.

By exploring the mechanism of action of $\mathrm{MgSO}_{4}$, we found that cellular magnesium content rapidly increased following $\mathrm{MgSO}_{4}$ exposure, in accordance with clinical data indicating that $\mathrm{MgSO}_{4}$ rapidly crosses the placenta, resulting in equivalent maternal and fetal concentrations. The anti-inflammatory effect was reversible, mediated by magnesium and not the sulfate moiety of the compound, and reduced cytokine production was unrelated to osmotic changes. $\mathrm{MgSO}_{4}$ exposure also decreased cytokine and I $\kappa \mathrm{Ba}$ gene expression, in addition to reducing phosphorylated NF- $\kappa \mathrm{B}$ p65 levels and NF- $\kappa \mathrm{B}$ nuclear localization following TLR4 stimulation, and decreased cytokine production was abrogated in the presence of NF- $\kappa \mathrm{B}$ inhibitors, proving that $\mathrm{MgSO}_{4}$ downregulates cytokine production in an $\mathrm{NF}-\kappa \mathrm{B}-$ dependent manner.

Using multiple TLR ligands, we further probed the breadth and mechanism of magnesium's action. $\mathrm{MgSO}_{4}$ supplementation reduced the percentage of monocytes producing TNF- $\mathrm{a}$ and IL-6 following TLR2/6 agonist exposure. Group B Streptococcus, Mycoplasma, and Ureaplasma express molecules recognized by TLRs 2 and 6 (28), demonstrating that our findings are applicable to pathogens prevalent within the clinical obstetrical setting. $\mathrm{MgSO}_{4}$ also decreased cytokine production following TLR3 ligand exposure. TLR3 is expressed intracellularly, signaling via IKKe/IRF3, a MyD88-independent/Toll/IL-1R domaincontaining adapter inducing IFN- $\beta$-dependent pathway. This result, combined with our observations that magnesium decreases cytokine production when added after LPS exposure and that cellular magnesium content increases following $\mathrm{MgSO}_{4}$ exposure, persuasively indicates that magnesium acts within the cell.

$\mathrm{NF}-\kappa \mathrm{B}$ is a central regulator of inflammation-induced cytokine production and is linked to cancer, diabetes, autoimmune diseases, and is critical to the development of the adaptive immune response. TLR4 and TLR2/6 activate the classical NF- $\kappa B$ pathway, whereas TLR3 
(TLR4 also has this capacity) utilizes a MyD88-independent/Toll/IL-1R domain-containing adapter inducing IFN- $\beta$-dependent pathway. Molecules shared by both pathways include $\mathrm{I} \kappa \mathrm{B} a$ and NF- $\kappa \mathrm{B}$. By evaluating I $\kappa \mathrm{B} a$ in monocytes, we found that magnesium increases basal I $\kappa \mathrm{B} a$ levels by $\sim 25 \%$ without effecting I $\kappa \mathrm{B} a$ gene expression. I $\kappa \mathrm{B} a$ has a short half life secondary to its proline, glutamic acid, serine, and threonine domain, which is thought to be responsible for constitutive proteolytic degradation and protein turnover (30-32). Based on these findings, I $\mathrm{B} a$ was quantitated in unstimulated cells treated with an inhibitor of protein synthesis prior to and during magnesium exposure. Magnesium enhanced preservation of I $\mathrm{KB} a$ levels in the absence of protein synthesis, suggesting that magnesium increases I $\kappa \mathrm{Ba}$ stability. This finding contrasts with observations in Hs294T cells whereby constitutive CXCL1 expression was associated with a shortened I $\kappa \mathrm{B} a$ half life, without changes in I $\kappa \mathrm{B} a$ mRNA levels (33); however, the overall conclusions demonstrating an inverse correlation between I $\kappa \mathrm{B} a$ half life and cytokine production are analogous. Although these findings do not preclude the possibility that magnesium influences other mediators within the TLR signaling cascade, our results strongly suggest that magnesium supplementation increases I $\kappa \mathrm{B} a$ levels, leading to reduced NF- $\kappa \mathrm{B}$ activation and cytokine production.

These studies were initiated secondary to recent randomized, controlled clinical trials establishing that antepartum $\mathrm{MgSO}_{4}$ treatment reduces the risk of cerebral palsy and major motor dysfunction in preterm infants (3-8). Inflammatory cytokines are found within periventricular leukomalacia lesions $(14,34,35)$; TNF- $\alpha$ and IL-1 $\beta$ exposure induce white matter glial cell death in animals (11); and epidemiologic studies associate increased neonatal serum TNF-a, IL-6, IL-8, IL-9, and RANTES levels with adverse neurologic outcomes (12-18). This knowledge led us to hypothesize that $\mathrm{MgSO}_{4}$ exerts its neuroprotective effect by downregulating inflammatory cytokine production. Our results support our hypothesis and correlate with the findings of clinical trials where $\mathrm{MgSO}_{4}$ treatment reduced the risk of cerebral palsy and major motor dysfunction in preterm infants (3-8). Importantly, we confirm the efficacy of $\mathrm{MgSO}_{4}$ at reducing inflammation in preterm neonates, the population at highest risk for the development of cerebral palsy.

$\mathrm{MgSO}_{4}$ has recently been shown to decrease maternal and fetal inflammation following LPS injection (36), whereas magnesium deficiency leads to cardiac dysfunction and inflammation, including increased TNF-a, IL-6, and IL-1 production in rats (37-39). $\mathrm{MgSO}_{4}$ also reduces inflammation-associated brain injury in fetal mice (40), supporting a link between magnesium, inflammation, and neurologic injury in rodents. In contrast, previous studies in humans have not found a correlation between magnesium levels and secreted cytokines $(41,42)$. These studies were limited by small samples sizes, measured serum cytokine levels in nonrandomized patients, or exposed diluted blood to a high LPS concentration. By using intracellular cytokine staining, we observed decreased cytokine production at low TLR ligand concentrations, where not all cells were induced to produce cytokines. In contrast, high TLR ligand concentrations abrogate the magnesium effect. These findings are consistent with clinical observations demonstrating that $\mathrm{MgSO}_{4}$ is not associated with increased maternal or neonatal mortality, particularly that secondary to infection (8).

In current obstetrical practice, $\mathrm{MgSO}_{4}$ is administered for seizure prophylaxis in pregnancies complicated by preeclampsia and as a tocolytic for preterm labor. The cytokines TNF-a and IL-6 are linked to both preterm birth and preeclampsia, and a recent study linked TLR4 signaling to seizure activity (23). In vivo $\mathrm{MgSO}_{4}$ exposure decreased inflammatory cytokine production, confirming clinical significance and leading us to conclude that magnesium's functions include decreasing maternal and neonatal inflammation associated with preterm labor, preeclampsia, and the development of cerebral palsy. $\mathrm{MgSO}_{4}$ is safe and well 
tolerated, and our findings suggest that magnesium could be used therapeutically as a broadspectrum anti-inflammatory agent.

Magnesium is the fourth most prevalent cation within the human body. However, $>90 \%$ of total body magnesium is intracellular, compartmentalized within organelles, bound to protein, or complexed to ATP (43). Extracellular ionized magnesium is readily measurable, but intracellular magnesium, which is not measured clinically and does not correlate with extracellular magnesium levels (44), is the biologically relevant form. This limitation in our ability to accurately evaluate magnesium status has been a critical barrier to progress in understanding the prevalence and impact of magnesium deficiency. Published work also suggests that the "Western diet" contains inadequate magnesium (45), predisposing individuals to deficiency that could be exacerbated by pregnancy. Within the fetus magnesium accumulation occurs after 28 wk gestation $(46,47)$, leading us to speculate that preterm infants are magnesium deficient. Our observations that $\mathrm{MgSO}_{4}$ exposure increased cellular magnesium levels within CBMCs and decreased cytokine production within preterm neonatal monocytes supports this concept. However, additional studies to determine magnesium levels at birth and delineate cellular magnesium concentrations limiting basal inflammation are needed.

Demonstrating that magnesium influences human innate immune function challenges current paradigms regarding immuno-regulation and the biologic function of magnesium. Likewise, a very recent study showed that magnesium influx is critical for appropriate TCRmediated T cell activation (48). Our results showing that $\mathrm{MgSO}_{4}$ decreases cytokine production are both novel and clinically relevant, but not without precedent, as zinc deficiency increases systemic inflammation and mortality in a sepsis model, whereas zinc supplementation decreases the incidence of age-related macular degeneration (49-51). Zinc mediates its function, in part, by upregulating the zinc-finger protein A20 inhibiting TRAFmediated NF- $\kappa \mathrm{B}$ activation (51); we show that $\mathrm{MgSO}_{4}$ also decreases NF- $\kappa \mathrm{B}$ activation. These findings expand our insight regarding micronutrients and molecular processes influencing immune function, potentially elucidating the mechanism by which $\mathrm{MgSO}_{4}$ mediates neuroprotection. Moreover, because maternal cytokine production is also reduced by $\mathrm{MgSO}_{4}$, our results could have far-reaching implications relevant to a wide range of inflammatory-mediated diseases, including the development of interventions inhibiting pathologic inflammation while leaving the immune system capable of responding appropriately.

\section{Supplementary Material}

Refer to Web version on PubMed Central for supplementary material.

\section{Acknowledgments}

H.B.B. received support from American Cancer Society Grant RSG-07-070-01-LIB.

We thank Method Duchon for critical reading of this manuscript, Joseph DiDonato for advice regarding I $\kappa \mathrm{B} a$ studies, and members of the Skowronski, Karn, Canaday, and Carlin Laboratories for reagents and help at various stages of this project.

\section{Abbreviations used in this article}

CBMC cord blood mononuclear cell

HAB human serum from $\mathrm{AB}$ donors 


$\begin{array}{ll}\text { ICS } & \text { intracellular cytokine staining } \\ \text { MALP } & \text { macrophage-activating lipopeptide } \\ \text { poly(I:C) } & \text { polyinosinic-polycytidylic acid }\end{array}$

\section{References}

1. Kuban KC, Leviton A, Pagano M, Fenton T, Strassfeld R, Wolff M. Maternal toxemia is associated with reduced incidence of germinal matrix hemorrhage in premature babies. J Child Neurol. 1992; 7:70-76. [PubMed: 1552156]

2. Schendel DE, Berg CJ, Yeargin-Allsopp M, Boyle CA, Decoufle P. Prenatal magnesium sulfate exposure and the risk for cerebral palsy or mental retardation among very low-birth-weight children aged 3 to 5 years. JAMA. 1996; 276:1805-1810. [PubMed: 8946900]

3. Magpie Trial Follow-Up Study Collaborative Group. The Magpie Trial: a randomised trial comparing magnesium sulphate with placebo for pre-eclampsia. Outcome for children at 18 months. BJOG. 2007; 114:289-299. [PubMed: 17166221]

4. Crowther CA, Hiller JE, Doyle LW, Haslam RR. Australasian Collaborative Trial of Magnesium Sulphate (ACTOMg SO4) Collaborative Group. . Effect of magnesium sulfate given for neuroprotection before preterm birth: a randomized controlled trial. JAMA. 2003; 290:2669-2676. [PubMed: 14645308]

5. Marret S, Marpeau L, Zupan-Simunek V, Eurin D, Lévêque C, Hellot MF, Bénichou J. PREMAG trial group. Magnesium sulphate given before very-preterm birth to protect infant brain: the randomised controlled PREMAG trial*. BJOG. 2007; 114:310-318. [PubMed: 17169012]

6. Mittendorf R, Dambrosia J, Pryde PG, Lee KS, Gianopoulos JG, Besinger RE, Tomich PG. Association between the use of antenatal magnesium sulfate in preterm labor and adverse health outcomes in infants. Am J Obstet Gynecol. 2002; 186:1111-1118. [PubMed: 12066082]

7. Rouse DJ, Hirtz DG, Thom E, Varner MW, Spong CY, Mercer BM, Iams JD, Wapner RJ, Sorokin Y, Alexander JM, et al. Eunice Kennedy Shriver NICHD Maternal-Fetal Medicine Units Network. . A randomized, controlled trial of magnesium sulfate for the prevention of cerebral palsy. N Engl J Med. 2008; 359:895-905. [PubMed: 18753646]

8. Doyle LW, Crowther CA, Middleton P, Marret S, Rouse D. Magnesium sulphate for women at risk of preterm birth for neuroprotection of the fetus. Cochrane Database Syst Rev. 2009;

(1):CD004661. [PubMed: 19160238]

9. Yeargin-Allsopp M, Van Naarden Braun K, Doernberg NS, Benedict RE, Kirby RS, Durkin MS. Prevalence of cerebral palsy in 8-year-old children in three areas of the United States in 2002: a multisite collaboration. Pediatrics. 2008; 121:547-554. [PubMed: 18310204]

10. Girard S, Kadhim H, Roy M, Lavoie K, Brochu ME, Larouche A, Sébire G. Role of perinatal inflammation in cerebral palsy. Pediatr Neurol. 2009; 40:168-174. [PubMed: 19218029]

11. Sherwin C, Fern R. Acute lipopolysaccharide-mediated injury in neonatal white matter glia: role of TNF-a, IL-1 $\beta$, and calcium. J Immunol. 2005; 175:155-161. [PubMed: 15972642]

12. Dammann O, Leviton A. Maternal intrauterine infection, cytokines, and brain damage in the preterm newborn. Pediatr Res. 1997; 42:1-8. [PubMed: 9212029]

13. Nelson KB, Dambrosia JM, Grether JK, Phillips TM. Neonatal cytokines and coagulation factors in children with cerebral palsy. Ann Neurol. 1998; 44:665-675. [PubMed: 9778266]

14. Rezaie P, Dean A. Periventricular leukomalacia, inflammation and white matter lesions within the developing nervous system. Neuropathology. 2002; 22:106-132. [PubMed: 12416551]

15. Romero R, Gotsch F, Pineles B, Kusanovic JP. Inflammation in pregnancy: its roles in reproductive physiology, obstetrical complications, and fetal injury. Nutr Rev. 2007; 65:S194S202. [PubMed: 18240548]

16. Shalak LF, Perlman JM. Infection markers and early signs of neonatal encephalopathy in the term infant. Ment Retard Dev Disabil Res Rev. 2002; 8:14-19. [PubMed: 11921381] 
17. Yoon BH, Romero R, Kim CJ, Koo JN, Choe G, Syn HC, Chi JG. High expression of tumor necrosis factor-a and interleukin-6 in periventricular leukomalacia. Am J Obstet Gynecol. 1997; 177:406-411. [PubMed: 9290459]

18. Yoon BH, Romero R, Yang SH, Jun JK, Kim IO, Choi JH, Syn HC. Interleukin-6 concentrations in umbilical cord plasma are elevated in neonates with white matter lesions associated with periventricular leukomalacia. Am J Obstet Gynecol. 1996; 174:1433-1440. [PubMed: 9065108]

19. Gomez R, Romero R, Ghezzi F, Yoon BH, Mazor M, Berry SM. The fetal inflammatory response syndrome. Am J Obstet Gynecol. 1998; 179:194-202. [PubMed: 9704787]

20. Romero R, Espinoza J, Gonçalves LF, Kusanovic JP, Friel L, Hassan S. The role of inflammation and infection in preterm birth. Semin Reprod Med. 2007; 25:21-39. [PubMed: 17205421]

21. Luppi P, Deloia JA. Monocytes of preeclamptic women spontaneously synthesize proinflammatory cytokines. Clin Immunol. 2006; 118:268-275. [PubMed: 16337193]

22. Schiessl B. Inflammatory response in preeclampsia. Mol Aspects Med. 2007; 28:210-219. [PubMed: 17532463]

23. Maroso M, Balosso S, Ravizza T, Liu J, Aronica E, Iyer AM, Rossetti C, Molteni M, Casalgrandi M, Manfredi AA, et al. Toll-like receptor 4 and high-mobility group box-1 are involved in ictogenesis and can be targeted to reduce seizures. Nat Med. 2010; 16:413-419. [PubMed: 20348922]

24. Kim YK, Mbonye U, Hokello J, Karn J. T-cell receptor signaling enhances transcriptional elongation from latent HIV proviruses by activating P-TEFb through an ERK-dependent pathway. J Mol Biol. 2011; 410:896-916. [PubMed: 21763495]

25. Romani A, Marfella C, Scarpa A. Regulation of magnesium uptake and release in the heart and in isolated ventricular myocytes. Circ Res. 1993; 72:1139-1148. [PubMed: 8495544]

26. Damsgaard CT, Lauritzen L, Calder PC, Kjaer TM, Frøkiaer H. Whole-blood culture is a valid low-cost method to measure monocytic cytokines: a comparison of cytokine production in cultures of human whole-blood, mononuclear cells and monocytes. J Immunol Methods. 2009; 340:95101. [PubMed: 19000693]

27. Jiang W, Lederman MM, Hunt P, Sieg SF, Haley K, Rodriguez B, Landay A, Martin J, Sinclair E, Asher AI, et al. Plasma levels of bacterial DNA correlate with immune activation and the magnitude of immune restoration in persons with antiretroviral-treated HIV infection. J Infect Dis. 2009; 199:1177-1185. [PubMed: 19265479]

28. Han YW, Shen T, Chung P, Buhimschi IA, Buhimschi CS. Uncultivated bacteria as etiologic agents of intra-amniotic inflammation leading to preterm birth. J Clin Microbiol. 2009; 47:38-47. [PubMed: 18971361]

29. Burger-Kentischer A I, Abele S, Finkelmeier D, Wiesmüller KH, Rupp S. A new cell-based innate immune receptor assay for the examination of receptor activity, ligand specificity, signalling pathways and the detection of pyrogens. J Immunol Methods. 2010; 358:93-103. [PubMed: 20385141]

30. DiDonato JA, Mercurio F, Karin M. Phosphorylation of I $\kappa \mathrm{B} a$ precedes but is not sufficient for its dissociation from NF- $k$ B. Mol Cell Biol. 1995; 15:1302-1311. [PubMed: 7862124]

31. Rechsteiner M, Rogers SW. PEST sequences and regulation by proteolysis. Trends Biochem Sci. 1996; 21:267-271. [PubMed: 8755249]

32. Rice NR, Ernst MK. In vivo control of NF- $\kappa$ B activation by IкBa. EMBO J. 1993; 12:4685-4695. [PubMed: 8223478]

33. Luan J, Shattuck-Brandt R, Haghnegahdar H, Owen JD, Strieter R, Burdick M, Nirodi C, Beauchamp D, Johnson KN, Richmond A. Mechanism and biological significance of constitutive expression of MGSA/GRO chemokines in malignant melanoma tumor progression. J Leukoc Biol. 1997; 62:588-597. [PubMed: 9365113]

34. Duggan PJ, Maalouf EF, Watts TL, Sullivan MH, Counsell SJ, Allsop J, Al-Nakib L, Rutherford MA, Battin M, Roberts I, Edwards AD. Intrauterine T-cell activation and increased proinflammatory cytokine concentrations in preterm infants with cerebral lesions. Lancet. 2001; 358:1699-1700. [PubMed: 11728550] 
35. Kadhim H, Tabarki B, De Prez C, Sébire G. Cytokine immuno-reactivity in cortical and subcortical neurons in periventricular leukomalacia: are cytokines implicated in neuronal dysfunction in cerebral palsy? Acta Neuropathol. 2003; 105:209-216. [PubMed: 12557006]

36. Tam Tam HB, Dowling O, Xue X, Lewis D, Rochelson B, Metz CN. Magnesium sulfate ameliorates maternal and fetal inflammation in a rat model of maternal infection. Am J Obstet Gynecol. 2011; 204:364.e1-8. [PubMed: 21272846]

37. Malpuech-Brugère C, Nowacki W, Rock E, Gueux E, Mazur A, Rayssiguier Y. Enhanced tumor necrosis factor-alpha production following endotoxin challenge in rats is an early event during magnesium deficiency. Biochim Biophys Acta. 1999; 1453:35-40. [PubMed: 9989243]

38. Shogi T, Oono H, Nakagawa M, Miyamoto A, Ishiguro S, Nishio A. Effects of a low extracellular magnesium concentration and endotoxin on IL-1 $\beta$ and TNF- $\alpha$ release from, and mRNA levels in, isolated rat alveolar macrophages. Magnes Res. 2002; 15:147-152. [PubMed: 12635865]

39. Weglicki WB, Phillips TM, Freedman AM, Cassidy MM, Dickens BF. Magnesium-deficiency elevates circulating levels of inflammatory cytokines and endothelin. Mol Cell Biochem. 1992; 110:169-173. [PubMed: 1584207]

40. Burd I, Breen K, Friedman A, Chai J, Elovitz MA. Magnesium sulfate reduces inflammationassociated brain injury in fetal mice. Am J Obstet Gynecol. 2010; 202:292.e1-9. [PubMed: 20207246]

41. Nowacki W, Malpuech-Brugère C, Rock E, Rayssiguier Y. High-magnesium concentration and cytokine production in human whole blood model. Magnes Res. 2009; 22:93-96. [PubMed: 19658279]

42. Mezad D, Hallak M, Huleihel M, Gortzak-Uzan L, Smolin A, Mazor M. Intravenous magnesium sulphate effect on maternal serum and amniotic fluid cytokines levels in preterm labour patients. Magnes Res. 2002; 15:247-252. [PubMed: 12635880]

43. Romani A. Regulation of magnesium homeostasis and transport in mammalian cells. Arch Biochem Biophys. 2007; 458:90-102. [PubMed: 16949548]

44. Franz KB. A functional biological marker is needed for diagnosing magnesium deficiency. $\mathrm{J}$ Am Coll Nutr. 2004; 23:738S-741S. [PubMed: 15637224]

45. Shils, ME. Magnesium. In: Shils, ME.; Olson, JA.; Shike, M.; Ross, AC., editors. Modern Nutrition in Health and Disease. Lippincott Williams \& Wilkins; New York: 1999. p. 169-192.

46. Caddell JL. A review of evidence for a role of magnesium and possibly copper deficiency in necrotizing enterocolitis. Magnes Res. 1996; 9:55-66. [PubMed: 8819095]

47. CIBA-Geigy. Geigy Scientific Tables. CIBA-Geigy; Basel, Switzerland: 1981.

48. Li FY, Chaigne-Delalande B, Kanellopoulou C, Davis JC, Matthews HF, Douek DC, Cohen JI, Uzel G, Su HC, Lenardo MJ. Second messenger role for $\mathrm{Mg}^{2+}$ revealed by human T-cell immunodeficiency. Nature. 2011; 475:471-476. [PubMed: 21796205]

49. Bao S, Liu MJ, Lee B, Besecker B, Lai JP, Guttridge DC, Knoell DL. Zinc modulates the innate immune response in vivo to polymicrobial sepsis through regulation of NF- $\kappa \mathrm{B}$. Am J Physiol Lung Cell Mol Physiol. 2010; 298:L744-L754. [PubMed: 20207754]

50. Knoell DL, Julian MW, Bao S, Besecker B, Macre JE, Leikauf GD, DiSilvestro RA, Crouser ED. Zinc deficiency increases organ damage and mortality in a murine model of polymicrobial sepsis. Crit Care Med. 2009; 37:1380-1388. [PubMed: 19242332]

51. Prasad AS. Zinc: role in immunity, oxidative stress and chronic inflammation. Curr Opin Clin Nutr Metab Care. 2009; 12:646-652. [PubMed: 19710611] 
A
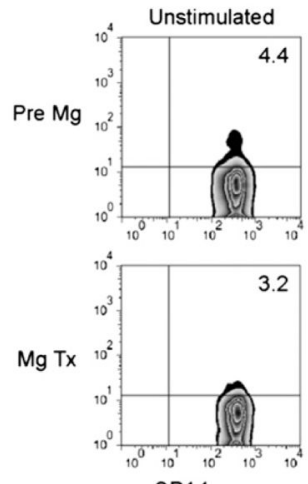

CD14

Relative Decrease: $\quad 27 \%$

B
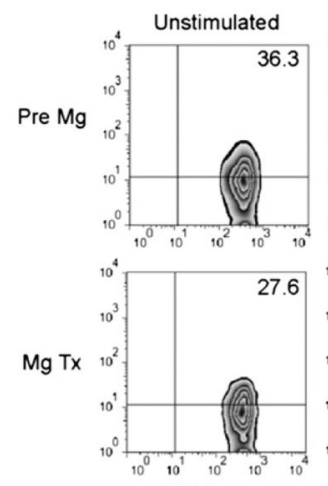

CD14

Relative Decrease: $\quad 25 \%$
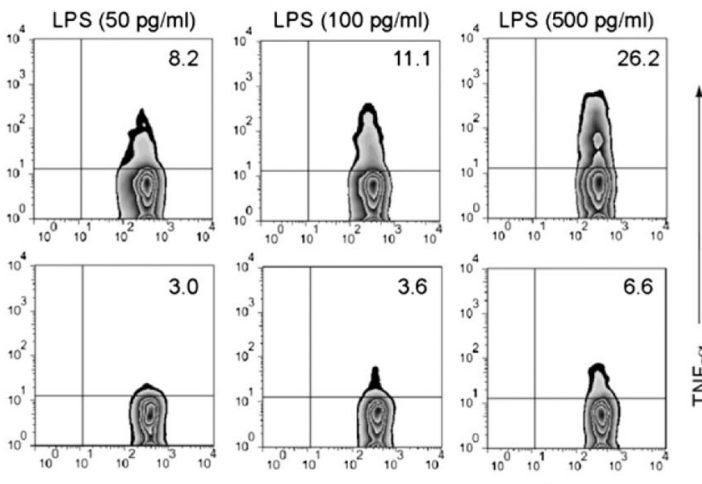

$63 \%$

$68 \%$

$75 \%$
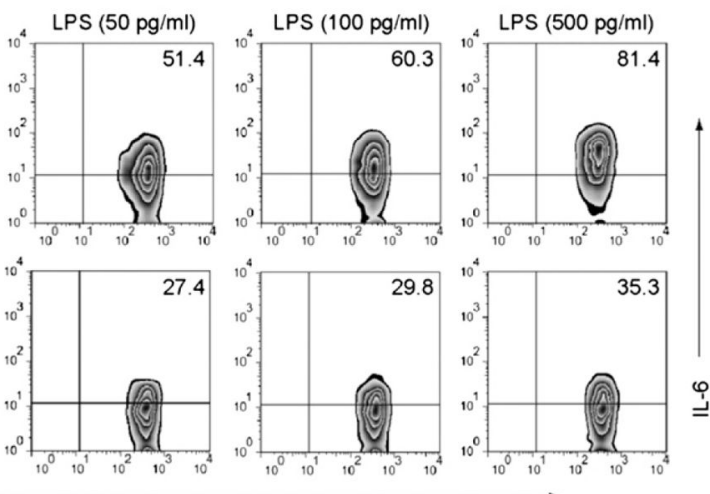

$47 \%$

$51 \%$

$57 \%$

FIGURE 1.

$\mathrm{MgSO}_{4}$ treatment in vivo and in vitro significantly decreases baseline and LPS-stimulated cytokine production. Heparinized maternal blood samples were obtained immediately prior (Pre $\mathrm{Mg}$ ) and 6-12 $\mathrm{h}$ after the initiation of clinically indicated parenteral $\mathrm{MgSO}_{4}$ treatment (Mg Tx). Unmanipulated whole blood was cultured in the presence or absence of LPS stimulation for $6 \mathrm{~h}$ with brefeldin A followed by ICS. The percentage of monocytes producing TNF-a (A) and IL-6 (B) are shown in the upper right quadrant of each dot plot; relative decreases in cytokine production for this patient are shown at the bottom of each section. Cumulatively, the frequency of monocytes producing TNF- $a$ was reduced by $25 \%$ $(p=0.03, n=7)$, and the frequency of IL-6-producing monocytes was reduced by $20 \%$ ( $p<$ $0.05, n=7$ ) following in vivo magnesium treatment. Similar reductions in cytokine expression were observed, as determined by the median fluorescence intensity within monocytes $(p<0.05)$. 

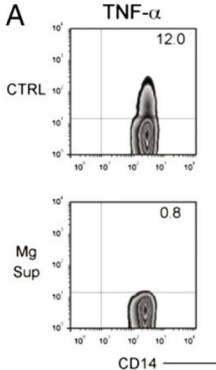
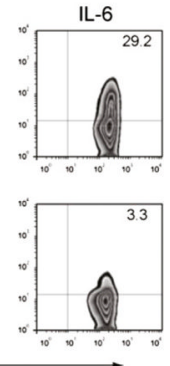
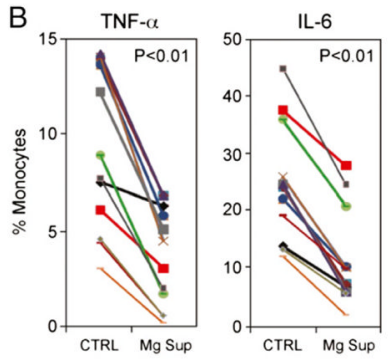
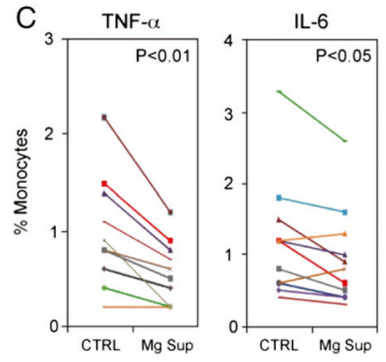

FIGURE 2.

$\mathrm{MgSO}_{4}$ decreases LPS-stimulated cytokine production in neonates. (A) $\mathrm{MgSO}_{4}$ supplementation decreases the percentage of stimulated monocytes producing TNF-a and IL-6. CBMCs cultured in RPMI 1640 (CTRL) or RPMI 1640 at a $\mathrm{MgSO}_{4}$ concentration of 6 $\mathrm{mg} / \mathrm{dl}$ (Mg Sup) were stimulated with $50 \mathrm{pg} / \mathrm{ml}$ LPS for $6 \mathrm{~h}$ with brefeldin A. Cells were stained with mAb CD14-FITC, permeabilized, stained with mAbs IL-6-PE, and TNF-aallophycocyanin, followed by flow cytometric analysis. The percentage of monocytes $\left(\mathrm{CD} 14^{+}\right.$cells) producing IL-6 or TNF-a is shown in the upper right corner of each plot, with monocytes comprising most of the cytokine-producing cells (>95\%). $\mathrm{MgSO}_{4}$ exposure significantly downregulates LPS-induced $(\mathbf{B})$ and basal $(\mathbf{C})$ cytokine production. The percentage of monocytes producing IL- 6 or TNF- $\alpha$ is shown $(n=12$, unique shapes delineate each individual), demonstrating that $\mathrm{MgSO}_{4}$ supplementation consistently decreases cytokine production in CBMCs. Data were analyzed using a Wilcoxon signedrank test. 

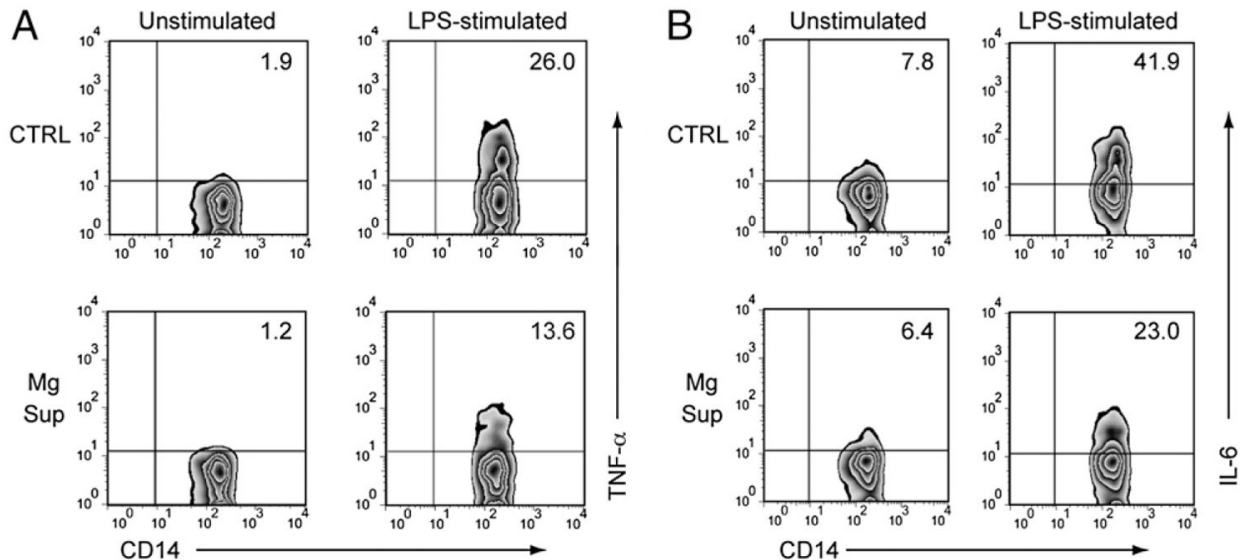

FIGURE 3.

$\mathrm{MgSO}_{4}$ decreases baseline and LPS-stimulated cytokine production in preterm infants. CBMCs from preterm infants ( $<34$ wk gestation, not exposed to $\mathrm{MgSO}_{4}$ intrapartum) were cultured with (MgSup) and without (CTRL) $\mathrm{MgSO}_{4}$ supplementation in the presence or absence of $50 \mathrm{pg} / \mathrm{ml}$ LPS stimulation. The results of ICS and flow cytometric analysis are shown: (A) TNF-a, (B) IL-6. Results are representative of five individual experiments. 

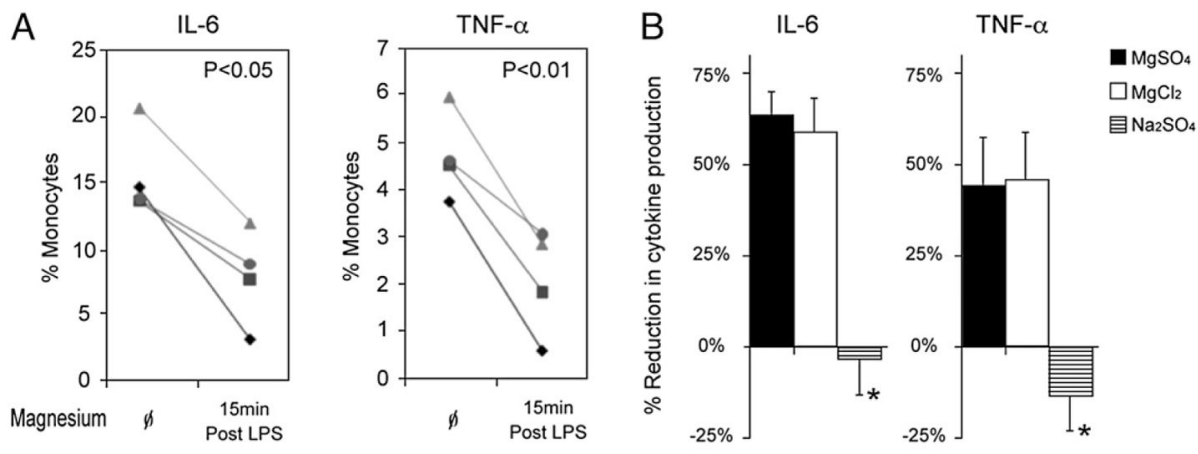

\section{FIGURE 4}

$\mathrm{MgSO}_{4}$ decreases cytokine production when added following LPS exposure, and decreased cytokine production is mediated by magnesium. (A) CBMCs were stimulated with LPS for 15 min prior to $\mathrm{MgSO}_{4}$ exposure (15 min Post LPS) to permit LPS/TLR binding. Inhibition of cytokine production was observed (at levels similar to those seen when $\mathrm{MgSO}_{4}$ and LPS are added simultaneously; $n=4$ ) and compared with cells from the same donor not supplemented with magnesium $(\phi)$. (B) CBMCs were stimulated with LPS alone, in the presence of $\mathrm{MgSO}_{4}$ supplementation $(2.5 \mathrm{mM})$, or with equimolar concentrations of related salts $\left(\mathrm{MgCl}_{2}\right.$ or $\left.\mathrm{Na}_{2} \mathrm{SO}_{4}\right)$. The percentage change in cytokine production for each salt was calculated based on ICS $\left(n=5,{ }^{*} p<0.01\right)$; SEM is shown. Both $\mathrm{MgCl}_{2}$ and $\mathrm{MgSO}_{4}$, decrease TNF- $\alpha$ and IL-6 production compared with untreated cells, whereas $\mathrm{Na}_{2} \mathrm{SO}_{4}$ failed to decrease cytokine production. 


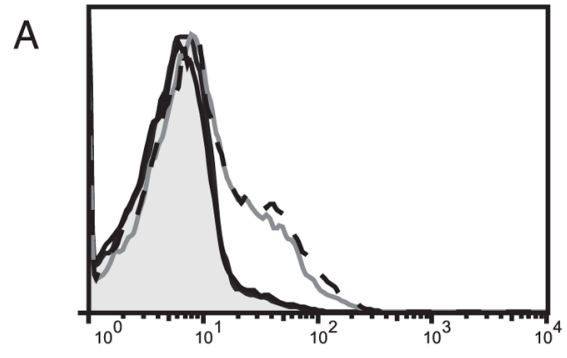

IL-6

B

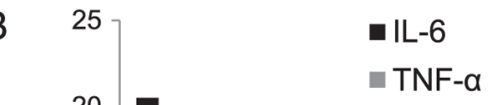

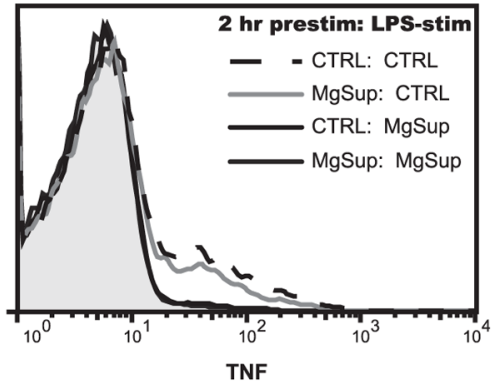

TNF

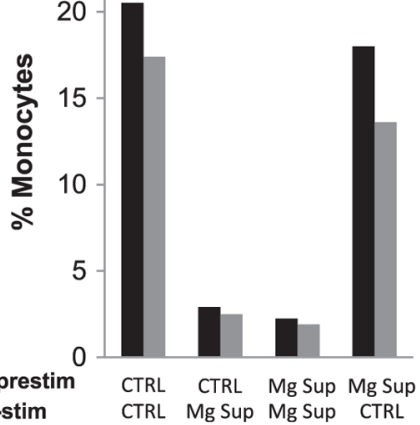

FIGURE 5.

$\mathrm{MgSO}_{4}$ causes a reversible decrease in cytokine production. CBMCs were exposed or not (CRTL) to magnesium supplementation (Mg Sup) for $2 \mathrm{~h}$. CBMCs were then washed and immediately challenged with LPS in the presence of control or magnesium supplemented media. (A) Histogram overlays show IL-6 and TNF-a production under each of the four conditions; the condition in which $\mathrm{Mg}^{2+}$ was supplemented prior to and during LPSstimulation is shaded gray. (B) Bar graph shows the percentage of neonatal monocytes producing either IL-6 (black) or TNF-a (gray) in the above histogram under each condition, illustrating that the effect of magnesium supplementation is reversible. Results are representative of three individual experiments. 
TNF- $\alpha$

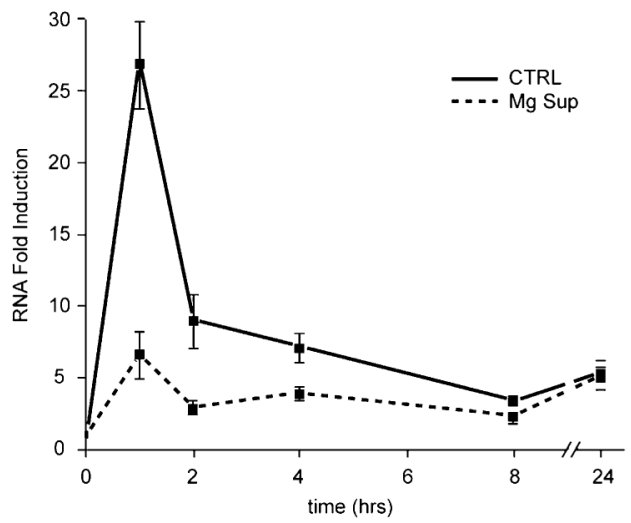

IL-6

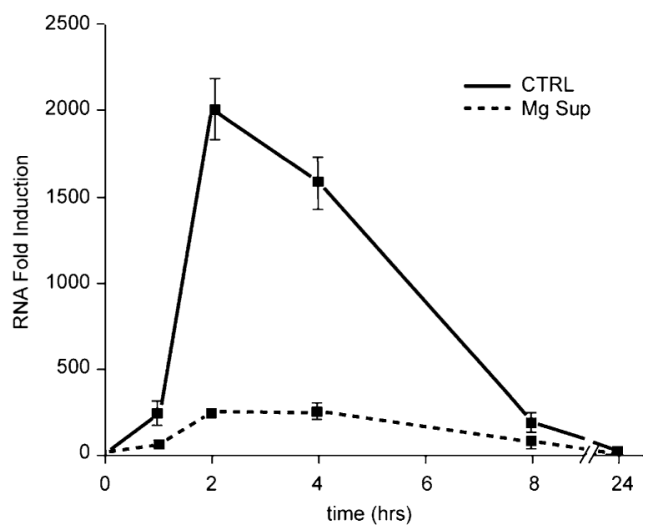

FIGURE 6.

$\mathrm{MgSO}_{4}$ decreases IL-6 and TNF-a gene expression following LPS stimulation. CBMCs in the presence (Mg Sup) or absence (CTRL) of magnesium supplementation were stimulated with LPS; RNA was extracted and reverse transcribed at the time points shown. Analysis of real-time PCR, showing the relative abundance of mRNAs encoding for IL-6 and TNF-a normalized relative to a stably expressed housekeeping gene (Gus), is shown. To control for differences in RNA extraction and RT, PCR efficiency samples were run in triplicate; error bars (SEM) are shown. For IL-6 at 1, 2, and $4 \mathrm{~h}$ time points and TNF-a at the 2 and $4 \mathrm{~h}$ time points, $p<0.05$. Data shown are representative of three individual experiments using different donors. 


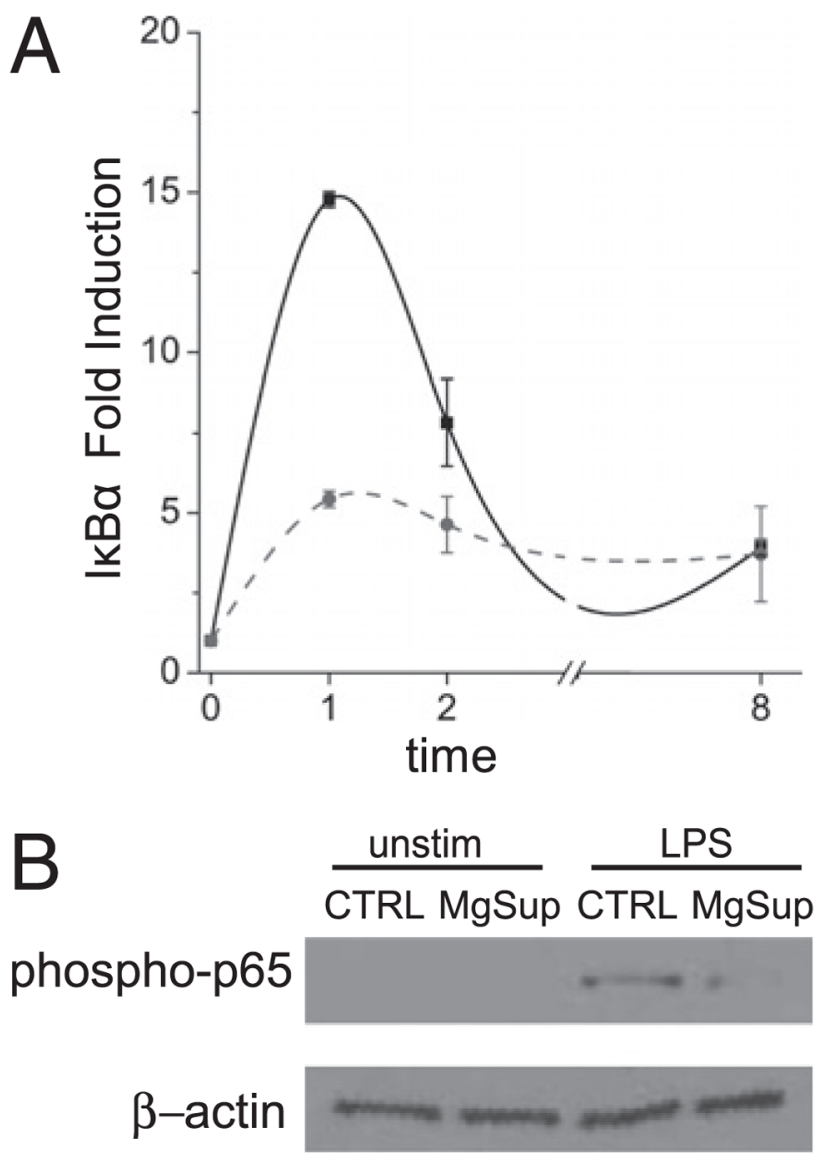

C

$$
\text { p65 }
$$

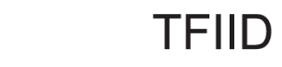

p65/TFIID ratio

2.7

$3.0 \quad 10.0$

5.0

FIGURE 7.

$\mathrm{MgSO}_{4}$ influences NF- $\kappa \mathrm{B}$ activation. (A) LPS-induced $\mathrm{I} \kappa \mathrm{Ba}$ gene expression is decreased in the presence of magnesium supplementation. CBMCs were stimulated with $50 \mathrm{pg} / \mathrm{ml}$ LPS, and relative I $\kappa \mathrm{Ba}$ gene expression, normalized to a stably expressed housekeeping gene, was assessed using real-time PCR at various time points. Gray circles/dashed line delineate magnesium-supplemented samples; black squares/solid line delineate control samples; error bars indicate the SEM of triplicate samples. (B) Magnesium exposure decreases phosphorylated NF- $\kappa \mathrm{B}$ p65 (S536) levels following TLR stimulation. CBMCs were stimulated for $30 \mathrm{~min}$, lysed, and proteins resolved by SDS-PAGE followed by Western blotting. Proteins were identified with specific rabbit polyclonal Abs and detected via HRP-conjugated secondary Abs and electrochemi-luminescence. Detection of $\beta$-actin demonstrates comparable protein loading; magnesium supplementation and LPS exposure are indicated at the bottom. (C) Magnesium reduces NF- $\kappa$ B p65 nuclear localization.

Neonatal monocytes were stimulated with LPS for 30 min; nuclear extracts were prepared 
and analyzed via Western blotting using labeled Abs and an infrared imaging system (Odyssey; Li-Cor Biosciences). TFIID quantitation was used as a protein loading control and the p65/TFIID ratio, representing relative p65 abundance in the nucleus, is shown beneath the blot. Results are representative of three experiments. 

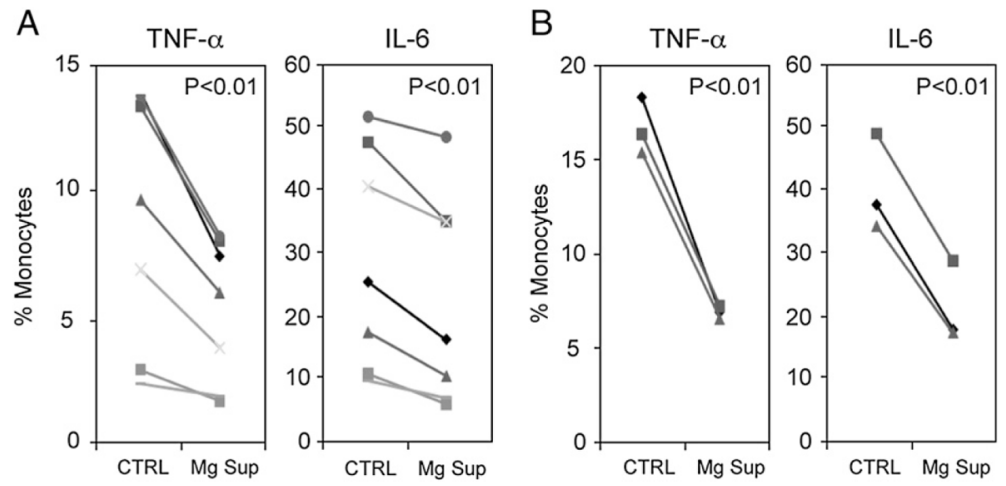

FIGURE 8.

$\mathrm{MgSO}_{4}$ decreases cytokine production induced by other TLR ligands. CBMCs in the presence (Mg Sup) or absence (CTRL) of $\mathrm{MgSO}_{4}$ supplementation were stimulated with (A) $1 \mathrm{ng} / \mathrm{ml}$ MALP-2 or (B) $1 \mu \mathrm{g} / \mathrm{ml}$ poly(I:C) and cytokine production was assessed via ICS. Magnesium decreased TNF- $a$ and IL-6 production following either MALP-2 (Wilcoxon signed-rank test, $n=7$ ) or poly(I:C) (Student $t$ test, $n=3$ ) stimulation; symbols identify paired samples from the same individual. 

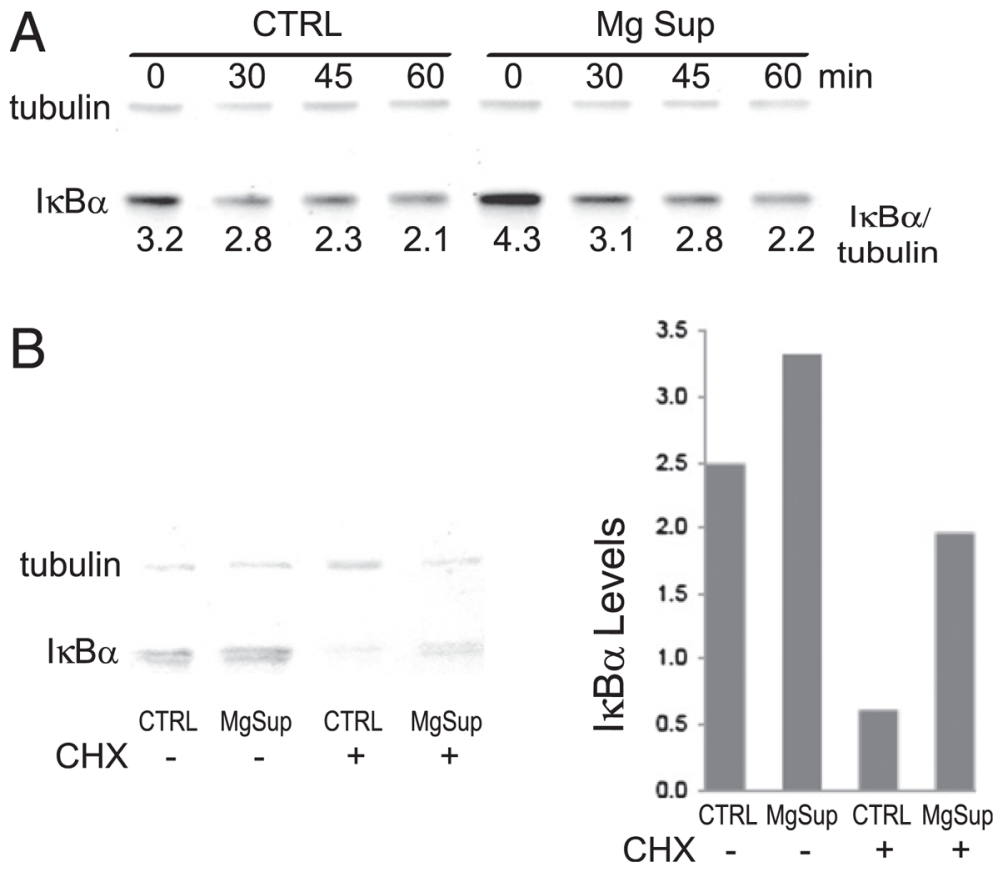

FIGURE 9.

$\mathrm{MgSO}_{4}$ increases I $\kappa \mathrm{Ba}$ levels. (A) Neonatal monocytes were stimulated with $50 \mathrm{pg} / \mathrm{ml}$ LPS, and IkBa levels, normalized to tubulin, a stably expressed housekeeping protein, were assessed at the indicated time points. Numbers below the blot indicate the I $\kappa \mathrm{Ba} /$ tubulin ratio, as calculated via infrared imaging, representing normalized I $\kappa$ Ba levels. (B) Cyclohexamide (CHX) treatment maintains increased I $\kappa$ Ba levels. THP-1 cells were treated with CHX, and after $1 \mathrm{~h}$ magnesium was added for an additional $2 \mathrm{~h}$ in the absence of stimulation. Cell lysates were analyzed by Western blotting, and IкBa levels under each condition are shown. Results are representative of three experiments. 